\title{
THEORY AND EVIDENCE ON MERGERS AND ACQUISITIONS BY SMALL AND MEDIUM ENTERPRISES
}

\author{
Utz Weitzel* \\ Utrecht University School of Economics, \\ Janskerkhof 12, 3512 BL Utrecht, the Netherlands \\ E-mail: u.weitzel@uu.nl \\ *Corresponding author \\ Max Planck Institute of Economics \\ Entrepreneurship, Growth and Public Policy Group \\ Kahlaische Straße 10, 07745 Jena, Germany

\section{Killian J McCarthy} \\ Rijksuniversiteit Groningen, \\ School of Economics and Business, \\ PO Box 800, 9700 AV Groningen, the Netherlands \\ E-mail: K.J.McCarthy@rug.nl
}

\begin{abstract}
The theory of mergers and acquisitions (M\&As) has been developed almost exclusively from the study of large deals by large firms. In this paper we argue that the behaviour and success of M\&As by small and medium sized enterprises (SMEs) may be significantly different. Accordingly, we revisit established M\&A theories, and develop a theoretical framework, and several testable hypotheses, regarding the distinctive features of SME M\&As. Our empirical results support our expectations and show that, compared to large firms, acquiring SMEs: rely more intensively on external growth via M\&As; are more likely to be withdrawn, suggesting that SMEs are more flexible, and more able to avoid deals that turn sour; and, finally, SME M\&As are more likely to be financed with equity rather than debt, indicating that the influential financial pecking order theory is of less relevance to SMEs.
\end{abstract}

Key words: mergers, acquisitions, small and medium sized enterprises 


\section{Introduction}

There is a long tradition of academic research on mergers and acquisitions (M\&A) within finance, business and economics. ${ }^{1}$ Since the very beginning, this has considered questions relating to performance evaluation and has been concerned, primarily, with issues relating, for example, to what sort of returns mergers generate, and for whom.

The focus of this research, however, has been on the role of the larger M\&A events, and precious little attention has been devoted to the question of small and medium sized enterprises (SMEs). Probably the most prominent reason for this is because most SMEs are not publicly quoted a fact which makes it difficult to obtain reliable data on their general activity, let alone to evaluate their M\&A performance records ${ }^{2}$.

And yet size does matter in mergers and acquisitions (see e.g., Moeller et al., 2004; 2005) and SMEs are anything but insignificant. In the European context, SMEs are thought to represent about $99 \%$ of all firms, to employ between them about 65 million people, and to drive innovation and competition. At a global level, SMEs may even be responsible for between $40 \%$ to $50 \%$ of world GDP (European Commission, 2005)

In this paper we attempt to include this important but long ignored sector of the economy, by explicitly considering the activity of the small and medium sized entrepreneurial firm within the M\&A industry.

We present direct and indirect evidence which suggests not only that the behaviour and financial success of mergers by SMEs may significantly differ from larger public firms, but also that the underlying merger theories which motivate these ventures might need to be revisited to account for this discrepancy. The existing evidence on mergers and acquisitions has been almost exclusively developed on the basis of large public firms and this, we suggest, needs to be corrected.

This paper makes a modest attempt at rectifying this long held bias. It does so by: firstly, studying and selecting the relevant merger theories; secondly, by translating these into a number of testable hypotheses on SME M\&As; and, finally, by empirically considering and commenting upon the applicability of these theories to the special case of SME M\&As.

\footnotetext{
${ }^{1}$ Although technically inaccurate, it is common practice within the literature to use the terms 'merger', 'acquisition', 'takeover' and 'M\&A' synonymously.

2 The vast majority of performance studies employ event study methodologies that rely on abnormal returns of publicly traded stock prices, and without an initial public offering, most small to medium sized, privately held entrepreneurial firms (especially in their early stages or when they simply are too small to be of any interest for public equity) are automatically excluded from these studies.
} 
In doing so, we find that, compared to large firms, acquiring SMEs are: (1) more likely to rely on M\&A as an external growth option; (2) more likely withdraw from a deal, a finding which, we suggest, implies that SMEs are more flexible, and better able to avoid deals that turn sour; and (3) that SME M\&As are more likely to be financed with equity over debt, indicating that the pecking order theory is of less relevance to SMEs.

The paper is structured as follows: Section Two begins by overviewing the literature on mergers, and by developing a number of hypotheses on how these might relate to SMEs. ${ }^{1}$ Section Three introduces the data and methodology, which we employ for testing, and Section Four discusses the results and major implications of our research. Section Five concludes the discussion by drawing implications, and by suggesting some potential avenues for future research on SME mergers and acquisitions.

\section{Literature and Hypotheses}

To understand the role of the SME within the M\&A industry we explore a number of questions. We begin by asking 'who' are the small and medium sized entrepreneurial firms of interest to our research? Secondly, we ask 'why' these SMEs merge, and 'why' we should expect them to perform differently to larger firms? Next, we consider 'how' we expect them to perform, and finally, we explore through 'what' mechanisms we expect SMEs to finance their mergers and acquisitions.

\subsection{Who are the SMEs?}

At present there is no consensus on the threshold at which enterprises are considered 'small', 'medium' or 'large'. As illustrated by Table 1, current European definitions, for example, categorise companies with fewer than 10 employees as being 'micro' enterprises, those with fewer than 50 as being "small", and those with fewer than 250 as "medium" (EU Commission, 2005). The US, by contrast, defines "small" as having fewer than 100 employees, and medium as having fewer than 500 .

The distinction of entrepreneurial firms is at least equally debated (see e.g., Johnson, 2007), and the existing merger data does not distinguish them along a predetermined working definition. At present, entrepreneurial firms are variously distinguished in terms of ownership profiles, innovativeness and risk attitudes, with the effect that markedly different sets of firms can be studied within the field entrepreneurship.

\footnotetext{
${ }^{1}$ Note that we focus on theories that explain individual mergers and not mergers waves. Several approaches attempt to explain a commonly observed wave-like pattern of mergers. See Martynova and Renneboog, 2008 for an excellent review.
} 
Based on the data available to us, however, and the focus of both the relevant empirical studies on mergers (see below) and on the economic role of entrepreneurial firms, we believe that it is reasonable to suggest that the (single) set of SMEs will overlap significantly with the set of entrepreneurial firms. We assume that, in general, entrepreneurial firms, and in particular nascent ventures, will be smaller firms, and also that they will have more private than public equity than the average of the total population of firms (see Johnson, 2007; Deakins and Freel, 2006). We fully appreciate that such a definition is imperfect, but suggest that, in the presence of data limitations, the overlap between the two will be sufficiently large to provide us with some useful results.

Table 1: European Commission SME Definitions

\begin{tabular}{lcccc}
\hline Category & Headcount & Turnover* & Assets $^{*}$ & Independence \\
\hline Micro Enterprises & $<10$ & $<=2 \mathrm{mil}$ & $<=2 \mathrm{mil}$ & no subsidiary \\
Small Enterprises & $<50 ;>=10$ & $<=10 \mathrm{mil}$ & $<=10 \mathrm{mil}$ & no subsidiary \\
Medium Enterprises & $<250 ;>=50$ & $<=50 \mathrm{mil}$ & $<=43 \mathrm{mil}$ & no subsidiary \\
Large Enterprises & $>=250$ & $>50 \mathrm{mil}$ & $>43 \mathrm{mil}$ & \\
\hline${ }^{*}$ At least one of these conditions have to be satisfied. & & \\
All monetary values in current Euros (also for U.S. bidders). & \\
${ }^{* *}$ The detailed conditions for independence are more complex (see source above)
\end{tabular}

\subsection{Why do SMEs Merge?}

The question of 'why' - 'why' do SMEs merge, and 'why' should we expect them to perform differently to large firms - is not so easily addressed. To answer these sorts of questions we must consider the applicability of the various merger theories, and must overview the literature which has been put forward to explain mergers in general. Due to the existence of some empirical findings, which suggest that mergers under-perform the market, this literature has been divided into two broad schools - the value-increasing, efficient market school, and valuedecreasing agency schools - and in our analysis we adopt this method.

\section{The Value-Increasing Theories}

According to the value increasing school, mergers occur, broadly, because mergers generate 'synergies' between the acquirer and the target, and synergies, in turn, increases the value of the firm (Hitt et al., 2001).

The theory of efficiency suggests, in fact, that mergers will only occur when they are expected to generate enough realisable synergies to make the deal beneficial to both parties; it is the symmetric expectations of gains which results in a 'friendly' merger being proposed and accepted. If the 
gain in value to the target was not positive, it is suggested, the target firm's owners would not sell or submit to the acquisition, and if the gains were negative to the bidders' owners, the bidder would not complete the deal. Hence, if we observe a merger deal, efficiency theory predicts value creation with positive returns to both the acquirer and the target. Banerjee and Eckard (1998) and Klein (2001) evidence this suggestion.

Following Chatterjee (1986), we must, however, distinguish between 'operative synergies' - or 'efficiency gains' achieved through economies of scale and scope - and 'allocative synergies' - or 'collusive synergies' resultant from increased market power and an improved ability to extract consumer surplus - when commenting on value creation in mergers and acquisitions. Most of the more recent literature concludes that operating synergies are the more significant source of gain (see e.g., Devos et al., 2008; Houston et al., 2001; Mukherjee et al., 2004) ${ }^{1}$, although it does also suggest that market power theory remains a valid merger motive. Increased 'allocative' synergies is said to offer the firm positive and significant private benefits (Feinberg, 1985) because, ceteris paribus, firms with greater market power charge higher prices and earn greater margins through the appropriation of consumer surplus. Indeed, a number of studies find increased profits and decreased sales after many mergers (Prager, 1992; Chatterjee, 1986; Kim and Singal, 1993; Sapienza, 2002; Cefis et al., 2008) - a finding which has been interpreted by many as evidence of increasing market power and allocative synergy gains (see e.g., Gugler et al., 2003). From a dynamic point of view too, market power is said to allow for the deterrence of potential future entrants (Motta, 2004; Besanko, 2006; Gugler et al., 2003), which can again afford the firm a significant premium, and so offer another long-term source of gain ${ }^{2}$.

In an efficient merger market the theory of corporate control provides a third justification, beyond simply synergistic gains, for why mergers must create value. It suggests that there is always another firm or management team willing to acquire an underperforming firm, to remove those managers who have failed to capitalise on the opportunities to create synergies, and thus to improve the performance of its assets (Weston et al., 2004). Managers who offer the highest value to the owners, it suggests, will take over the right to manage the firm until they themselves are replaced by another team that discovers an even higher value for its assets.

\footnotetext{
${ }^{1}$ Mukherjee et al. (2004) find that $90 \%$ of managers identify operative motives as a reason to merge, and Devos et al. (2008) suggest that, of a total $10.3 \%$ synergy gain, some $8.3 \%$ arise through operative synergies.

${ }^{2}$ Few bidders, of course, openly announce the goal of increased market power as an explicit merger motivation, but the fact that horizontal mergers - that is, mergers between competitors - dominate the M\&A industry (Gugler et al., 2003) is surely indicative of just how popular it is as a merger motive.
} 
Hence, inefficient managers will supply the 'market for corporate control' (Manne, 1965), and managers that do not maximise profits will not survive, even if the competitive forces on their product and input markets fails to eliminate them. 'Hostile' takeovers should, as a result, be observed amongst poorly performing firms, and amongst those whose internal corporate governance mechanisms have failed to discipline their managers. Once again the empirical evidence again seems to support this conclusion (see e.g., Hasbrouck, 1985; Palepu, 1986).

From the bidder's perspective, the theory of corporate control is partially based on efficiency theory, although there are two important differences. First, it does not assume, per se, the existence of synergies between the corporate assets of both firms, but rather between the bidder's managerial capabilities and the targets assets. Hence, corporate control predicts managerial efficiencies from the re-allocation of under-utilized assets. Second, it implies that the target's management team is likely to resist takeover attempts, as the team itself and its managerial inefficiency is the main obstacle to an improved utilization of assets. Typical bidders are either private investors - or 'corporate raiders'- who bring in more competent management teams, or more efficient firms, as measured by Tobin's Q, with better growth prospects and superior performance.

\section{The Value-Destroying Theories}

The impact of mergers and acquisitions on the performance of the acquiring firm remains, however, at best, "inconclusive" and, at worst, "systematic[ally] detrimental" (Dickerson et al., 1997). Mergers fail to create value, it is suggested - with somewhere between 60 and $80 \%$ classified as 'failures' (Puranam and Singh, 1999) - and a number of value destroying theories have been put forward in explanation.

Generally speaking, these value-destroying theories can be divided into two groups: the first assumes that the bidder's management is 'boundedly rational', and thus makes mistakes and incurs losses due to informational constraints despite what are generally value-increasing intentions. The second assumes rational but self-serving managers, who maximise a private utility function, which at least fails to positively affect firm value.

Within the first category, the theory of managerial hubris (Roll, 1986) suggests that managers may have good intentions in increasing their firm's value but, being over-confident, they over-estimate their abilities to create synergies. Over-confidence increases the probability of overpaying (Hayward and Hambrick, 1997; Malmendier and Tate, 2008), and may 
leave the winning bidder in the situation of a winner's-curse ${ }^{1}$, which dramatically increases the chances of failure (Dong et al., 2006). Empirically speaking, Berkovitch and Narayanan (1993) find strong evidence of hubris in US takeovers, and Goergen and Renneboog (2004) find the same in a European context. The latter estimate that about one third of the large takeovers in the 1990s suffered from some form of hubris. Malmendier and Tate (2005) show that overly optimistic managers, who voluntarily retain in-the-money stock options in their own firms, more frequently engage in less profitable diversifying mergers, and Rau and Vermaelen (1998) find that hubris is more likely to be seen amongst low book-to-market ratio firms - that is, amongst the so-called 'glamour firms' - than amongst high book-to-market ratio 'value firms'.

Jensen's (1986) theory of managerial discretion claims that it is not over-confidence that drives unproductive acquisitions, but rather the presence of excess liquidity, or free cash flow (FCF). Firms whose internal funds are in excess of the investments required to fund positive net present value projects, it is suggested, are more likely to make quick strategic decisions, and are more likely to engage in large-scale strategic actions with less analysis than their cash-strapped peers. High levels of liquidity increase managerial discretion, making it increasingly possible for managers to choose poor acquisitions when they run out of good ones (Martynova and Renneboog, 2008). Indeed, several empirical studies demonstrate that the abnormal share price reaction to takeover announcements by cash-rich bidders is negative and decreasing in the amount of FCF held by the bidder (see e.g., Harford, 1999). Moreover, it is suggested that the other stakeholders in the firm will be more likely to give management the benefit of the doubt in such situations, and to approve acquisition plans on the basis of fuzzy and subjective concepts such as managerial 'instincts', 'gut feelings' and 'intuition', based on high past and current cash flows (Rau and Vermaelen, 1998). Thus, like the hubris theory, the theory of FCF suggests that otherwise well-intentioned mangers make bad decisions, not out of malice, but simply because the quality of their decisions are less challenged than they would be in the absence of excess liquidity.

Of course, as the degree of managerial discretion increases in FCF, or in high market valuations (as in the case of 'glamour firms' above), or in other proxies, so, too, does the opportunity for self-interested managers to pursue self-serving acquisitions (Jensen, 2005). It is generally agreed that managerial self-interest does play a role in M\&A; research has shown that

\footnotetext{
1 The winner's curse is a phenomenon that occurs in common value auctions with incomplete information. If the auctioned item is worth roughly the same to all bidders, the winner is the bidder who makes the highest estimate of its value. If we assume that the average bid is accurate, the winning bidder overpays.
} 
bidder returns are, for example, generally higher when the manager of the acquiring firm is a large shareholder (Lewellen et al., 1985), and lower when management is not (Lang et al., 1991; Harford 1999). This suggests that managers pay more attention to an acquisition when they themselves are financially concerned. Further, it supports the notion of 'agency cost' and the 'managerial theories' of the firm' (Berle and Means, 1932; Marris, 1963), which broadly suggest that managers pursue self-serving acquisitions, and it is this fact that leads to value-destruction.

The theory of managerial entrenchment (Shleifer and Vishny, 1989), for example, claims that unsuccessful mergers occur because managers primarily make investments that minimise the risk of replacement. It suggests that managers pursue projects not in an effort to maximise enterprise value, but in an effort to entrench themselves by increasing their individual value to the firm. Entrenching managers will, accordingly, make manager-specific investments that make it more costly for shareholders to replace them, and value will be reduced because free resources are invested in manager-specific assets rather than in a shareholder value-maximising alternative. Amihud and Lev (1981) empirically support this notion, and suggest that managers pursue diversifying mergers in order to decrease earnings volatility which, in turn, enhances corporate survival and protects their positions.

Of course, entrenchment is not only pursued for job security itself, but also because entrenched managers may be able to extract more wealth, power, reputation and fame. While entrenchment theory primarily explains the process of how managers position themselves to achieve these objectives, the theory of empire-building and other related, well-tested theories provide both the motivations and evidence behind these objectives (Marris, 1963; 1964; Ravenscraft and Scherer, 1987; Rhoades, 1983; Black, 1989). According to empire theory, managers are explicitly motivated to invest in the growth of their firm's revenues (sales) or asset base, subject to a minimum profit requirement (Marris, 1963). ${ }^{2}$

1 Shleifer and Vishny (1991) suggest that during the third merger wave risk diversification played a large role in M\&A policy - as prior to the 1980s managers had insufficient incentive to focus on shareholder concerns - and it has been suggested that the rise of the conglomerate may be an outgrowth of this principleagent problem (Martynova and Renneboog, 2008).

${ }^{2}$ Mueller (1969) introduced mergers as a vehicle for growth maximization (not profit maximization), and Williamson (1964) complements this by introducing company cars, excess staff or prestigious investments as complementary motives. Rhoades (1983) analyses the third merger wave, and shows that managerial power serves as an explanation of firm growth through M\&A, and concludes that the power motive replaced the profit motive as the driving force behind large companies' behaviour. 
The merger theories described above has evolved from the analysis of relatively large-scale deals by public acquirers, with little effort being explicitly made to understanding the role of SMEs. However, we suggest that SMEs are, different to their larger rivals, for at least two reasons.

Table 2: Refining the set of Applicable Merger Motives

\begin{tabular}{|c|c|c|c|c|c|}
\hline Outcome & Benefits & How? & Theory & Link & SMEs? \\
\hline \multirow{3}{*}{ Gains } & \multirow{3}{*}{ Owners } & $\begin{array}{l}\text { Net gains through } \\
\text { operative synergies }\end{array}$ & Efficiency & \multirow{3}{*}{ Synergy } & High \\
\hline & & $\begin{array}{l}\text { Wealth transfers } \\
\text { from customers }\end{array}$ & Market Power & & Medium \\
\hline & & $\begin{array}{l}\text { Net gains through } \\
\text { managerial } \\
\text { synergies }\end{array}$ & $\begin{array}{l}\text { Corporate } \\
\text { Control }\end{array}$ & & Medium \\
\hline \multirow{4}{*}{ Losses } & \multirow{2}{*}{$\begin{array}{l}\text { Owner } \\
\text { Intended }\end{array}$} & $\begin{array}{l}\text { Net losses though } \\
\text { overpaying }\end{array}$ & Hubris & \multirow{2}{*}{$\begin{array}{l}\text { Bounded } \\
\text { Rationality }\end{array}$} & Medium \\
\hline & & $\begin{array}{l}\text { Net losses due to } \\
\text { valuation mistakes }\end{array}$ & $\begin{array}{l}\text { Managerial } \\
\text { Discretion }\end{array}$ & & Medium \\
\hline & \multirow[t]{2}{*}{ Manager } & $\begin{array}{l}\text { Net losses as } \\
\text { managers make } \\
\text { acquisitions to } \\
\text { reinforce job } \\
\text { positions }\end{array}$ & Entrenchment & \multirow{2}{*}{$\begin{array}{l}\text { Agency } \\
\text { Costs }\end{array}$} & Low \\
\hline & & $\begin{array}{l}\text { Net losses as } \\
\text { managers make } \\
\text { acquisitions to } \\
\text { increase firm size }\end{array}$ & $\begin{array}{l}\text { Empire } \\
\text { Building }\end{array}$ & & Low \\
\hline
\end{tabular}

Firstly, we suggest that because the manager is often the owner in the case of an SME, many of the value-destroying theories discussed above will simply not apply. Most of the value-destroying theories we considered arose out of agency problems - that is, problems of competing and not overlapping objective functions - which occur with the separation of ownership and control. In the case of owner-mangers, however, principle-agent costs are removed, and so the theories of entrenchment and empire-building are unlikely to play a part in SME M\&As.

Secondly, and even in the case of a principle-agent structure, we suggest that the information asymmetries, which facilitate self-interested behaviour, will be reduced in the case of SMEs. Larger firms, we suggest, have deeper hierarchies, more dispersed responsibilities and more 
complex systems of accountability then their smaller peers, and this obstructs transparency and information symmetries. We suggest that the level of information asymmetry suffered by the firm is inversely related to its size, and that smaller firms will allow self-interested managers fewer opportunities to act in a self-interested way. Thus the likelihood that agency motives will play a role in SMEs is significantly reduced.

By refining the set of merger motives to exclude the agency motives (see Table 2), we can clearly see that SME M\&As will more often be made in the interests of the owners. Only hubris and the problems of overvaluation remain as potential sources of value destruction, but according to Moeller et al., (2004) these too should be less of a problem in SMEs. Moeller et al., (2004) examines a sample of 12,023 mergers over the period 1980 to 2001 and finds that large firms are more likely to complete a deal then small firms because, they suggest, hubris is more of a problem for larger firms. Managers in smaller firms, they suggested, are as likely to make the same boundedly rational mistakes as their colleagues in larger firms, but because the interests of managers in small firms are more closely aligned with the owners, the managers in small firms are more likely to withdraw from a deal once they realise their mistakes (for instance, in a due diligence prior to consummation). Evidence that the number of value-destroying mistakes is reduced in the case of SMEs should thus be found by looking at the number of withdrawn bids, and so we operationalise our intuition that value-destroying motives are less likely to play a role with SME M\&As with the following hypothesis:

Hypothesis 1: SMEs are more likely to withdraw from (arguably valuedestroying) mergers than large enterprises

\subsection{How do SMEs perform in M\&As?}

From the preceding discussion we can assume that SME M\&As face a higher probability of successful mergers than their larger rivals. They face lower agency costs, and are more likely to be withdrawn when motivated, we suggest, by mistakes and misevaluations. Because of this we believe that SME M\&A will, on average, demonstrate superior performance.

Precious little attention has been paid, however, to the role of the SME performance within the M\&A industry. The near standard methodology in most M\&A research is, in fact, to place a lower limit on deal value typically in the range of $\$ 10$ to $\$ 50$ million - with the deliberate intention of excluding smaller firms with smaller deals (e.g., Schlingemann, 2004). 
Research has shown, however, that size matters when it comes to performance, and that the two are inversely related. Carline et al. (2002), for example, shows that larger deal values predict poorer performance, and this has lead to the suggestion that smaller firms, making smaller deals, may make better acquirers. Moeller et al $(2004,2005)$ empirically confirm this suggestion. Defining small firms as those firms whose capitalisation falls below the 25th percentile of NYSE, Moeller et al (2004) show that small acquisitions made by small firms are typically profitable, whereas large firms making large acquisitions often result in large dollar losses. In their sample they find that shareholders from small firms earned roughly $\$ 9$ billion from their acquisitions during the period 1980-2001, whereas shareholders from large firms made significant losses over the period of about $\$ 312$ billion. Defining 'large loss deals' as acquisitions with shareholder wealth losses in excess of $\$ 1$ billion, Moeller et al (2005) find, in fact, that while such mega-loss deals represent only $2.1 \%$ of all M\&A events which occurred in the period 1998-2001, they account for $43.4 \%$ of the money spent on acquisitions. By doing so, Moeller et al. (2005) show that relatively few large loss-making deals contribute significantly and disproportionally to the low average performance of mergers, and provide some solid evidence that small firms may perform above average.

Consequently, the literature suggests that smaller firms, on average, will make for better acquirers, and because furthermore the M\&As that they pursue will be more likely to create value, we believe that M\&A is likely to be an important growth strategy for SME. We predict that SME managers will be aware of this, and consequently we predict that SMEs will make up a sizable proportion of the annual M\&A population.

Hypothesis 2: SMEs that pursue external growth and engage in $M \& A$ activities, do so with the same or even greater intensity than large enterprises.

\subsection{How do SMEs finance M\&As?}

Mergers and acquisitions are big business - average deal size (based on disclosed prices) was $\$ 198.2$ million in 2006 (Wilmerhale, 2007) - and this raises the question as to how SMEs go about raising M\&A finance.

Myers and Majluf (1984) argue that different funds come at different costs for different firms. For public firms, they suggest, external financing options are more costly than internal financing options, because external capital is subject to adverse selection and transaction costs caused by the existence of asymmetric information between the firms managers and its 
investors. Internally generated cash - in the form of free cash and retained earnings - is not subject to these costs, and so is the cheapest form of capital $^{1}$. Several studies have shown that cash-financed deals are, consequently, more beneficial (or at least less detrimental) to bidding shareholders (e.g., Carow et al., 2004; Huang and Walking, 1987).

With externally sourced options, debt is cheaper than equity because convincing one bank to invest, it is suggested, incurs less costs than convincing a group of own/old acquirer shareholders to vote for an M\&A deal, and to dilute their stock, before then convincing a group of target/new shareholders to accept this new stock (Carpenter, 1995). Thus, Myers and Mailuf (1984) propose a financial 'pecking order hypothesis' in the form: internal cash, then debt and then equity.

We suggest that, for the special case of SME financing, the theory does not fully apply. Internal cash reserves will, we argue, remain the preferred source of capital for SMEs but, because of their special features, the relative costs and benefits of using debt and equity will differ.

We have already argued that many SMEs are owner-managed, and so if the holdings of old shareholders are diluted - for example, by the issue of new stocks for the target shareholders to finance the deal with a stock-forstock exchange - then this will be done, we suggest, by managers who are also incumbent shareholders, and thus free from information asymmetries. Bae et al. (2002) find some supportive evidence for this conclusion.

Using the same argument, we suggest that the costs involved in convincing the target shareholders to accept the stock of the acquirer will also be lower for SMEs. SMEs, it is argued, buy smaller targets, which are also more often owner-managed than larger enterprise. If these target managers, sitting on the other side of the table, go through all the negotiations and all the due diligence reports with the owner-managers of the acquirer, then the information symmetry faced by them, as receivers of the newly issued shares, will also be reduced. Furthermore, it is suggested that even if some of firms are publicly quoted, SMEs typically will have more concentrated block-holders than larger firms with more atomistic ownership, which makes it easier to approach and easier to convince. Because these shareholders will also have a seat in the board, they will again face relatively less information asymmetries to their larger rivals.

In contrast, going to a bank, remains a relatively costly option. Next to the costs of negotiating with the acquirer - which in the case above, would

\footnotetext{
${ }^{1}$ Indeed a number of studies suggest that firms with internal cash reserves are better able to adapt to a changing business environment (see e.g., Bruner, 1988, Wan and Yin, 2009), and excess liquidity and financial slack is an important feature for innovative firms (see e.g., Nohria and Gulanti, 1996, Damanpour, 1987, Majumdar and Venkataraman, 1993, Singh, 1986) experimenting with new products, technologies or markets (e.g., Majumdar and Venkataraman, 1993, Moses, 1992).
} 
be sufficient to arrange a stock-for-stock exchange - a third party, the banks, is required in the case of debt, and these too have to be convinced to finance the deal. Smaller companies tend to be less transparent than larger companies, and this creates difficulties for banks, and raises costs. Thus, the pecking order for SMEs is cash, then stock and then debt. If the deal is too large to be financed with internal cash/retained earnings, stockfor-stock-exchange is, we argue, the next best means of financing.

For SMEs, financing with internal cash is an unlikely scenario. SMEs are unlikely to have the necessary liquid resources to cover the cost of an acquisition, and cognisant of the importance of retaining a 'cushion of liquidity' (Cyert and March, 1963), they are unlikely to over-utilise their internal options. Cash in SME transactions will more likely come from external debt sources, and because we have argued that these represent the more costly option, we expect that the consideration paid to the target will be comprised of more stock and less cash than the average large deal. This leads us to postulate a third and final hypothesis on SMEs and M\&As:

Hypothesis 3: SMEs use more stock and less cash as means of payment than large enterprises.

\section{Data \& Methodology}

\subsection{Sample Design}

To test our hypotheses on M\&As between SMEs we employ data from Thomson Reuters' well-known SDC merger database, and analyse all acquisitions that satisfy the following conditions. (1) the acquisition is announced between January 1, 1996 and December 31, 2007; (2) the acquisition is either completed or withdrawn, but not pending or rumoured; (3) the acquirer is located either in the U.S. or in Western Europe $^{1}$; (4) the target is located in the same country as the acquirer; (5) the acquisition does not involve a recapitalisation, self-tender, repurchase of shares, privatization, or spin-off to existing shareholders; (6) the acquirer is not operating in the financial sector (SIC 6000-6999), in public administration (two-digit-SIC 91-99), or in an unknown industry (SIC 0000); (7) the acquirer and the target are not owned by the same ultimate

\footnotetext{
${ }^{1}$ As defined in the database, including Andorra, Austria, Belgium, Cyprus, Denmark, Faroe Islands, Finland, France, Germany, Gibraltar, Greece, Greenland, Guernsey, Vatican City, Iceland, Isle of Man, Italy, Jersey, Liechtenstein, Luxembourg, Malta, Monaco, Netherlands, Norway (incl. Svalbard/Jan Mayer Islands), Portugal, Republic of Ireland, San Marino, Spain, Sweden, Switzerland, United Kingdom.
} 
parent; (8) the acquirer seeks full ownership of the target; and (9) the variables needed to run our analyses (see next section) are not missing. This refinement process produces a sample of 17,137 M\&A observations. We classify acquirers according to the latest European Commission definitions on SMEs (see Table 2), as derived by Johnson (2007).

\subsection{Variable Description}

As dependent variables in our analysis we use: (1) deal value per merger and deal frequency per acquirer normalised with (that is, divided by) total assets, total sales, and number of employees of acquirer; (2) the percentage of stock, cash, other in consideration; and (3) a dummy for completed merger $(=1,0=$ withdrawn $)$. As independent variables we use: (1) a dummy for micro firms, small firms, medium firms, large firms, each; and (2) a dummy for SMEs (non-large firms=1, large firms=0).

Furthermore, and as an extensive body of literature shows that a number of firm- and deal-specific characteristics affect M\&A behaviour (see King, et al., 2004 for an overview), we include a number of control variables in our model to account for unobserved effects. We include:

Public versus Private: Officer (2007), Chang (1998) and Bargeron et al (2007) each provide evidence that returns in publicly listed firms differs significantly from private targets, and so we control for: (1) the acquirer and (2) the target by status (using a dummy in each case)

Hostility: The hostility of the takeover has been shown to impact returns, although here the evidence is somewhat mixed (Schwert, 2000). To account for this possibility, however, we include an indicator variable equal to 1 if the target's board officially rejects the bid.

Size: As Moeller et al. (2004, 2005) shows, large deals often under perform, and therefore we include the log of the deal value (not used in regressions in M\&A intensity - dependent variables (1) above - as then deal value would be on the left and right hand side of estimation)

Consideration: It has been shown that stock payments are more frequently associated with lower returns to acquirer shareholders (see e.g., Andrade, Mitchell and Stafford, 2001). To control for this, we include the percentage of consideration paid in cash and stock (but not in the case of $\mathrm{H} 3$ testing, as it is dependent variable there).

Time, Type, Trends \& Location: Furthermore, we dummy for (1) the location of the acquirer (in US=1, 0 if otherwise); (2) time, so as to control for the possibility of year- and seasonal-specific unobserved 
effects; and finally, (3) industries, on the basis of SIC 1 level codes, so as to capture industry-specific effects. Finally, we use the year of the merger as a count variable to capture trending effects.

Table 3: SME Mergers per year and industry

\begin{tabular}{|c|c|c|c|c|c|c|}
\hline $\begin{array}{l}\text { No. of deals in... } \\
\text { per... }\end{array}$ & $\begin{array}{c}\text { micro } \\
\text { enterprises }\end{array}$ & $\begin{array}{c}\text { small } \\
\text { enterprises }\end{array}$ & $\begin{array}{c}\text { medium } \\
\text { enterprises }\end{array}$ & $\begin{array}{c}\text { large } \\
\text { enterprises }\end{array}$ & Total & SME in $\%$ \\
\hline \multicolumn{7}{|l|}{ YEAR } \\
\hline 1996 & 3 & 21 & 190 & 1,004 & 1,218 & $17.6 \%$ \\
\hline 1997 & 2 & 22 & 249 & 1,368 & 1,641 & $16.6 \%$ \\
\hline 1998 & 6 & 48 & 243 & 1,576 & 1,873 & $15.9 \%$ \\
\hline 1999 & 14 & 95 & 364 & 1,385 & 1,858 & $25.5 \%$ \\
\hline 2000 & 28 & 108 & 421 & 1,293 & 1,850 & $30.1 \%$ \\
\hline 2001 & 22 & 76 & 222 & 981 & 1,301 & $24.6 \%$ \\
\hline 2002 & 26 & 61 & 147 & 956 & 1,190 & $19.7 \%$ \\
\hline 2003 & 29 & 59 & 147 & 869 & 1,104 & $21.3 \%$ \\
\hline 2004 & 19 & 88 & 225 & 951 & 1,283 & $25.9 \%$ \\
\hline 2005 & 23 & 66 & 192 & 996 & 1,277 & $22.0 \%$ \\
\hline 2006 & 18 & 84 & 177 & 1,017 & 1,296 & $21.5 \%$ \\
\hline 2007 & 24 & 53 & 178 & 991 & 1,246 & $20.5 \%$ \\
\hline Total & 214 & 781 & 2,755 & 13,387 & 17,137 & $21.9 \%$ \\
\hline \multicolumn{7}{|l|}{ INDUSTRY (acq) } \\
\hline Agriculture & 1 & 0 & 12 & 61 & 74 & $17.6 \%$ \\
\hline Mining & 40 & 42 & 62 & 458 & 602 & $23.9 \%$ \\
\hline Construction & 2 & 7 & 38 & 300 & 347 & $13.5 \%$ \\
\hline Manufacturing & 52 & 226 & 822 & 5,100 & 6,200 & $17.7 \%$ \\
\hline Transp.,Utility & 1 & 14 & 65 & 850 & 930 & $8.6 \%$ \\
\hline Communication & 11 & 51 & 135 & 947 & 1,144 & $17.2 \%$ \\
\hline Wholesale,Retail & 18 & 54 & 165 & 1,375 & 1,612 & $14.7 \%$ \\
\hline Services & 89 & 387 & 1,456 & 4,296 & 6,228 & $31.0 \%$ \\
\hline Total & 214 & 781 & 2,755 & 13,387 & 17,137 & $21.9 \%$ \\
\hline \multicolumn{7}{|l|}{ LOCATION } \\
\hline Western Europe & 32 & 280 & 857 & 2,880 & 4,049 & $28.9 \%$ \\
\hline USA & 182 & 501 & 1,898 & 10,507 & 13,088 & $19.7 \%$ \\
\hline Total & 214 & 781 & 2,755 & 13,387 & 17,137 & $21.9 \%$ \\
\hline \multicolumn{7}{|l|}{ STATUS (tar) } \\
\hline target public & 54 & 203 & 797 & 6,595 & 7,649 & $13.8 \%$ \\
\hline target private & 160 & 578 & 1,958 & 6,792 & 9,488 & $28.4 \%$ \\
\hline Total & 214 & 781 & 2,755 & 13,387 & 17,137 & $21.9 \%$ \\
\hline
\end{tabular}

\section{Results}

\subsection{Descriptives}

Table 3 reports the number of M\&A deals per year, industry, location and by type, according to the European Commissions definitions of micro, small, medium and large enterprises, as well as the total number of deals. From it we can make a number of important observations: 
Firstly, we can clearly see that, as Moeller et al (2005) suggest, small M\&As are overwhelmed in the average statistics by large M\&A: 214 micro-enterprise $M \& A s$ versus 13,387 large firm deals. Despite this we see that SMEs account for about $20 \%$ of the total deals over the period; with a high in 2000, when SMEs accounted for 30\%, and a low in 1998 at a level of $15.9 \%$. This are, we suggest, sizable numbers.

Secondly, and looking at the industry level, we see that SME M\&As are more often observed in services and manufacturing, and least often in transportation and utilities. As the latter are the most likely to be subject to minimum efficient scale considerations, this result is an intuitive one.

Thirdly, we see that, in absolute terms, the lions share of the SME M\&As is in the US (2581 versus 1169), but that relatively speaking, proportionally more SME M\&As occurred in Europe. During the period January 1996 to December 2007, 28.9\% of all Western European M\&As were SME orientated, as opposed to $19.7 \%$ of all American M\&As.

Finally, we see that - in all three of our SME categories, and in comparison to larger firms too - private targets are much more common than public targets in our sample. This observation provides some suggestive evidence in favour of our third hypothesis.

Table 4: Pairwise Correlations

\begin{tabular}{|c|c|c|c|c|c|c|c|c|c|c|c|c|c|}
\hline & & Mean & S.D. & Min & $\operatorname{Max}$ & 1 & 2 & 3 & 4 & 5 & 6 & 7 & 8 \\
\hline 1 & completed deal & 0.96 & 0.20 & 0.00 & 1.00 & & & & & & & & \\
\hline 2 & target size (log deal value) & 3.25 & 2.10 & -6.91 & 12.01 & $\begin{array}{l}-0.13 \\
(0.00)\end{array}$ & & & & & & & \\
\hline 3 & acquirer privately owned & 0.01 & 0.10 & 0.00 & 1.00 & $\begin{array}{c}0.01 \\
(0.38)\end{array}$ & $\begin{array}{l}-0.03 \\
(0.00)\end{array}$ & & & & & & \\
\hline 4 & target privately owned & 0.55 & 0.50 & 0.00 & 1.00 & $\begin{array}{c}0.11 \\
(0.00)\end{array}$ & $\begin{array}{l}-0.33 \\
(0.00)\end{array}$ & $\begin{array}{c}0.00 \\
(0.51)\end{array}$ & & & & & \\
\hline 5 & target friendly & 0.99 & 0.12 & 0.00 & 1.00 & $\begin{array}{c}0.27 \\
(0.00)\end{array}$ & $\begin{array}{c}-0.12 \\
(0.00)\end{array}$ & $\begin{array}{c}0.01 \\
(0.35)\end{array}$ & $\begin{array}{c}0.07 \\
(0.00)\end{array}$ & & & & \\
\hline 6 & paid in cash (pct) & 41.03 & 44.67 & 0.00 & 100.00 & $\begin{array}{c}0.05 \\
(0.00)\end{array}$ & $\begin{array}{c}0.01 \\
(0.11)\end{array}$ & $\begin{array}{l}-0.03 \\
(0.00)\end{array}$ & $\begin{array}{l}-0.08 \\
(0.00)\end{array}$ & $\begin{array}{c}-0.01 \\
(0.11)\end{array}$ & & & \\
\hline 7 & paid in stock (pct) & 24.59 & 38.95 & 0.00 & 100.00 & $\begin{array}{l}-0.12 \\
(0.00)\end{array}$ & $\begin{array}{c}0.11 \\
(0.00)\end{array}$ & $\begin{array}{l}-0.03 \\
(0.00)\end{array}$ & $\begin{array}{c}0.07 \\
(0.00)\end{array}$ & $\begin{array}{l}-0.01 \\
(0.40)\end{array}$ & $\begin{array}{l}-0.46 \\
(0.00)\end{array}$ & & \\
\hline 8 & paid other (pct) & 8.43 & 19.97 & 0.00 & 100.00 & $\begin{array}{c}0.02 \\
(0.04)\end{array}$ & $\begin{array}{l}-0.03 \\
(0.00)\end{array}$ & $\begin{array}{l}-0.02 \\
(0.01)\end{array}$ & $\begin{array}{c}0.10 \\
(0.00)\end{array}$ & $\begin{array}{c}0.01 \\
(0.25)\end{array}$ & $\begin{array}{l}-0.15 \\
(0.00)\end{array}$ & $\begin{array}{l}-0.12 \\
(0.00)\end{array}$ & \\
\hline 9 & acquirer in U.S. & 0.76 & 0.42 & 0.00 & 1.00 & $\begin{array}{l}-0.02 \\
(0.02)\end{array}$ & $\begin{array}{c}0.25 \\
(0.00)\end{array}$ & $\begin{array}{c}-0.03 \\
(0.00)\end{array}$ & $\begin{array}{l}-0.07 \\
(0.00)\end{array}$ & $\begin{array}{c}0.02 \\
(0.00)\end{array}$ & $\begin{array}{l}-0.07 \\
(0.00)\end{array}$ & $\begin{array}{c}0.12 \\
(0.00)\end{array}$ & $\begin{array}{c}-0.13 \\
(0.00)\end{array}$ \\
\hline
\end{tabular}

Table 4 then reports on the pairwise correlation for a number of important variables employed in the study. We also check for multicollinearity, which does not appear to be a serious issue in this study.

\subsection{Hypothesis One: On Withdrawn and Completed Mergers}

We suggest that M\&As amongst SMEs are more likely to be motivated by value-enhancing objectives in general, and less likely than larger firms to complete a value-destroying deal made subject to bounded rationality. 
SME M\&As, we suggest, are less likely to be completed when driven by overvaluations, mistakes or miscalculations, and so SMEs are more likely than larger firms to be withdrawn. We test this hypothesis by looking at the percentage of withdrawn and completed deals per firm category.

Table 5 reports the results of this investigation on a univariate basis. From this we can clearly see some evidence in support of our hypothesis that the increasing size of the firm and the proportion of the deals that they complete are positively related. Small and micro-firms complete less deals than medium sized firms, who in turn complete less deals than larger firm.

Table 5: The Percentage of Completed Deals by Firm Size

\begin{tabular}{|c|c|}
\hline Enterprise size & completed $^{*}$ \\
\hline micro & $93.93 \%$ \\
\hline small & $92.06 \%$ \\
\hline medium & $95.17 \%$ \\
\hline large & $96.35 \%$ \\
\hline Total & $95.93 \%$ \\
\hline
\end{tabular}

Table 6 investigates the relationship further, and presents the results of a logistic maximum likelihood estimation, which uses a dummy for completed mergers as the dependent variable. Instead of coefficients we report the odds ratios for a better understanding of the economic effects. From the results we can see that the relationship between increasing firm size and the increasing likelihood of a withdrawal is robust: each of the disaggregated size categories (micro, small and medium) for the acquiring firm, as well as the aggregated SME variable, are significant at the $1 \%$ level. The odds ratios for all three size category dummies are clearly below 1, which indicates that they are less likely to complete a merger than large firms. For micro firms and small firms, the odds of completing a merger are, respectively, 0.195 and 0.162 times the odds of a large firm to complete. In other words, the odds to withdraw from a deal are more than 5 times as large $(1 / 0.195=5.13,1 / 0.162=6.17)$ than the odds for a large firm. For medium sized firms, the odds of deal completion (0.336) are roughly two times higher than for micro and small firms. This deal completion likelihood, however, is still only about third of that for large firms. The same is true for the SME dummy in Model 3, which shows the combined effect of the three individual size dummies.

Table 6: Logistic maximum likelihood estimation 


\begin{tabular}{|c|c|c|c|}
\hline \multirow{2}{*}{\begin{tabular}{|l|} 
Dependent \\
Logit estimation
\end{tabular}} & \multicolumn{3}{|c|}{ Completed deal dummy } \\
\hline & Model 1 & Model 2 & Model 3 \\
\hline \multirow[t]{2}{*}{ micro enterprise } & & $0.195^{\star \star \star}$ & \\
\hline & & {$[-4.937]$} & \\
\hline \multirow[t]{2}{*}{ small enterprise } & & $0.162^{\star \star \star}$ & \\
\hline & & {$[-9.858]$} & \\
\hline medium enterprise & & $\begin{array}{l}0.336^{\star * *} \\
{[-8.590]}\end{array}$ & \\
\hline SME & & & $\begin{array}{c}0.284^{* *} \\
{[-10.855]}\end{array}$ \\
\hline acquirer privately owned & $\begin{array}{c}1.117 \\
{[0.193]}\end{array}$ & $\begin{array}{c}1.322 \\
{[0.505]}\end{array}$ & $\begin{array}{c}1.286 \\
{[0.452]}\end{array}$ \\
\hline target privately owned & $\begin{array}{c}2.525^{\star * *} \\
{[9.062]}\end{array}$ & $\begin{array}{c}2.657^{* * *} \\
{[9.457]}\end{array}$ & $\begin{array}{c}2.652^{* * *} \\
{[9.488]}\end{array}$ \\
\hline target friendly & $\begin{array}{c}20.830^{\star * *} \\
{[19.225]}\end{array}$ & $\begin{array}{c}21.080^{\star * \star} \\
{[19.195]}\end{array}$ & $\begin{array}{c}21.188^{\star * *} \\
{[19.220]}\end{array}$ \\
\hline target size (log deal value) & $\begin{array}{l}0.887^{\star \star \star} \\
{[-5.040]}\end{array}$ & $\begin{array}{l}0.787^{\star \star \star} \\
{[-9.453]}\end{array}$ & $\begin{array}{l}0.796^{\star \star \star} \\
{[-9.067]}\end{array}$ \\
\hline acquirer in U.S. & $\begin{array}{c}1.087 \\
{[0.704]}\end{array}$ & $\begin{array}{c}1.065 \\
{[0.522]}\end{array}$ & $\begin{array}{c}1.061 \\
{[0.494]}\end{array}$ \\
\hline trend variable (year) & $\begin{array}{c}1.02 \\
{[0.887]}\end{array}$ & $\begin{array}{c}1.036 \\
{[1.595]}\end{array}$ & $\begin{array}{c}1.031 \\
{[1.372]}\end{array}$ \\
\hline paid in cash (pct) & $\begin{array}{c}1.001 \\
{[0.414]}\end{array}$ & $\begin{array}{c}1 \\
{[0.191]}\end{array}$ & $\begin{array}{c}1 \\
{[0.233]}\end{array}$ \\
\hline paid in stock (pct) & $\begin{array}{l}0.987^{\star * *} \\
{[-9.725]}\end{array}$ & $\begin{array}{l}0.990^{* * *} \\
{[-7.089]}\end{array}$ & $\begin{array}{l}0.990^{* * *} \\
{[-7.460]}\end{array}$ \\
\hline constant & $\begin{array}{c}0 \\
{[-0.871]}\end{array}$ & $\begin{array}{c}0 \\
{[-1.562]}\end{array}$ & $\begin{array}{c}0 \\
{[-1.341]}\end{array}$ \\
\hline year dummies & $y$ & $y$ & $y$ \\
\hline industry dummies & $y$ & $\mathrm{y}$ & $y$ \\
\hline P-Micro-Small & & 0.5958 & \\
\hline P-Small-Medium & & 0.0001 & \\
\hline P-Micro-Medium & & 0.0995 & \\
\hline observations (N) & 17137 & 17137 & 17137 \\
\hline clusters (N) & 6166 & 6166 & 6166 \\
\hline chi square & 802.451 & 921.247 & 905.81 \\
\hline Nagelkerke r2 & 0.155 & 0.179 & 0.176 \\
\hline prob > chi2 & 0 & 0 & 0 \\
\hline \multicolumn{4}{|c|}{$\begin{array}{l}\text { Table reports odds ratios with robust variance estimators. } \\
\text { P-Micro-Small is the p-value in a Wald (1940) test that compares the coefficients } \\
\text { of the micro and small enterprise dummies. If the null hypothesis is rejected, } \\
\text { the coefficients are not equal to each other. P-Small-Medium and P-Micro-Medium } \\
\text { are computed analogously. The standard errors in all models allow for correlation } \\
\text { between mergers by the same acquirer. }\end{array}$} \\
\hline
\end{tabular}

We also test for differences between the odds ratios of three size categories. Table 6 reports the p-values of the null hypothesis that the odds ratios of the three dummies are equal (see Wald, 1940). While we find no statistical difference between the deal completion likelihoods of micro firms and small firms, the odds ratios of both size categories differ at a $10 \%$ and a $0.01 \%$ confidence level from medium sized firms. The control 
variables, target firm size, measured as the natural logarithm of the deal value, also has a statistically significant odds ratio below one. Further, we find that the greater the percentage of stock offered in the deal the greater the likelihood that the deal will be withdrawn. Following Moeller et al., (2004), we interpret an increased likelihood of withdrawal to signal a reduction in the proportion of value-destruction, and so infer that SME M\&As are less likely to be pursued for value-destroying reasons.

\subsection{Hypothesis Two: On M\&A Popularity}

Our second hypothesis suggest that, because SME M\&As are more likely to be pursued for value-increasing motives, SMEs will pursue external growth opportunities through mergers, and will engage in M\&A activity with the same - if not greater - intensity than large enterprises. We test this by looking at the frequency of deals and the deal size, normalised over total assets, number of employees, and total sales. Table 7 presents the results of results of univariate results of our investigation. From this already we can clearly see that SMEs which merge at least once in the observed period (i.e. enter the sample) rely significantly more heavily on external growth than large firms in the same period.

Table 7: $M \& A s$ amongst SMEs

\begin{tabular}{|l|cccc|}
\hline Enterprise size & $\begin{array}{c}\text { deal value/ } \\
\text { employee }^{*}\end{array}$ & $\begin{array}{c}\text { deal value/ } \\
\text { assets* }^{*}\end{array}$ & $\begin{array}{c}\text { deal value/ } \\
\text { sales }^{*}\end{array}$ & $\begin{array}{c}\text { deal no./ } \\
\text { assets }^{*}\end{array}$ \\
\hline micro & 5.686 & 584.783 & 107.123 & 8 \\
small & 0.599 & 197.192 & 12.004 & 1.28 \\
medium & 0.226 & 30.4 & 1.096 & 0.211 \\
large & 0.108 & 0.778 & 0.267 & 0.022 \\
Total & 0.219 & 21.784 & 2.27 & 0.209 \\
\hline
\end{tabular}

* SME average statistically different from large enterprise average at 0.05 significance level (two-sided ttest)

Table 8 presents the results of an OLS regression which further explores this finding, and employs a number of different measures of merger intensity as the dependent variable. For all models we use a Breusch-Pagan (1980) test to investigate whether or not the disturbances are normally distributed. As Table 8 shows, the corresponding p-values reject this null hypothesis. We therefore use heteroskedasticity-consistent estimators of variance in all models.

Table 8: $M \& A s$ amongst SMEs 


\begin{tabular}{|c|c|c|c|c|c|c|c|c|}
\hline \multirow{2}{*}{$\begin{array}{l}\text { Dependent } \\
\text { OLS estimation }\end{array}$} & \multicolumn{2}{|c|}{$\begin{array}{l}\text { deal value / } \\
\text { total sales }\end{array}$} & \multicolumn{2}{|c|}{$\begin{array}{l}\text { deal value / } \\
\text { total assets }\end{array}$} & \multicolumn{2}{|c|}{$\begin{array}{l}\text { deal value / } \\
\text { employees }\end{array}$} & \multicolumn{2}{|c|}{$\begin{array}{l}\text { deal freq. / } \\
\text { total assets }\end{array}$} \\
\hline & Model 1 & Model 2 & Model 3 & Model 4 & Model 5 & Model 6 & Model 7 & Model 8 \\
\hline micro enterprise & $\begin{array}{c}107.088^{\star \star} \\
{[2.384]}\end{array}$ & & $\begin{array}{c}586.949^{\star \star} \\
{[2.214]}\end{array}$ & & $\begin{array}{l}5.571^{\star * *} \\
{[4.290]}\end{array}$ & & $\begin{array}{l}7.953^{\star \star *} \\
{[5.649]}\end{array}$ & \\
\hline small enterprise & $\begin{array}{l}11.821^{* *} \\
{[2.136]}\end{array}$ & & $\begin{array}{c}195.274^{*} \\
{[1.846]}\end{array}$ & & $\begin{array}{l}0.508^{* * *} \\
{[8.764]}\end{array}$ & & $\begin{array}{l}1.254^{* * *} \\
{[4.147]}\end{array}$ & \\
\hline medium enterprise & $\begin{array}{c}0.663^{*} \\
{[1.917]}\end{array}$ & & $\begin{array}{c}28.624^{* *} \\
{[2.463]}\end{array}$ & & $\begin{array}{c}0.126^{* * *} \\
{[6.031]}\end{array}$ & & $\begin{array}{c}0.194^{\star \star *} \\
{[7.364]}\end{array}$ & \\
\hline SME & & $\begin{array}{c}9.160^{* * *} \\
{[3.075]}\end{array}$ & & $\begin{array}{c}95.406^{* * *} \\
{[3.422]}\end{array}$ & & $\begin{array}{l}0.521^{* * *} \\
{[6.460]}\end{array}$ & & $\begin{array}{l}0.864^{* * *} \\
{[7.517]}\end{array}$ \\
\hline acquirer privately owned & $\begin{array}{c}-1.829 \\
{[-1.323]}\end{array}$ & $\begin{array}{c}-1.547 \\
{[-1.149]}\end{array}$ & $\begin{array}{c}-39.109^{* *} \\
{[-2.226]}\end{array}$ & $\begin{array}{l}-32.702^{* *} \\
{[-2.538]}\end{array}$ & $\begin{array}{l}-0.115^{\star *} \\
{[-2.058]}\end{array}$ & $\begin{array}{l}-0.109^{* *} \\
{[-2.424]}\end{array}$ & $\begin{array}{c}-0.079 \\
{[-0.847]}\end{array}$ & $\begin{array}{c}-0.048 \\
{[-0.550]}\end{array}$ \\
\hline target privately owned & $\begin{array}{c}0.599 \\
{[0.991]}\end{array}$ & $\begin{array}{c}1.017 \\
{[1.370]}\end{array}$ & $\begin{array}{l}-15.536 \\
{[-1.164]}\end{array}$ & $\begin{array}{l}-12.763 \\
{[-0.971]}\end{array}$ & $\begin{array}{l}-0.115^{\star * *} \\
{[-3.318]}\end{array}$ & $\begin{array}{c}-0.095^{\star * *} \\
{[-2.626]}\end{array}$ & $\begin{array}{c}0.056 \\
{[1.564]}\end{array}$ & $\begin{array}{l}0.088^{* *} \\
{[2.237]}\end{array}$ \\
\hline target friendly & $\begin{array}{l}-1.446^{\star *} \\
{[-2.368]}\end{array}$ & $\begin{array}{l}-1.111^{* *} \\
{[-1.998]}\end{array}$ & $\begin{array}{c}4.65 \\
{[0.547]}\end{array}$ & $\begin{array}{c}6.687 \\
{[0.731]}\end{array}$ & $\begin{array}{l}-0.199^{* * *} \\
{[-3.453]}\end{array}$ & $\begin{array}{c}-0.183^{\star \star \star} \\
{[-3.168]}\end{array}$ & $\begin{array}{c}-0.012 \\
{[-0.573]}\end{array}$ & $\begin{array}{c}0.013 \\
{[0.461]}\end{array}$ \\
\hline acquirer in U.S. & $\begin{array}{c}0.608 \\
{[0.473]}\end{array}$ & $\begin{array}{c}2.103 \\
{[1.170]}\end{array}$ & $\begin{array}{c}-5.757 \\
{[-0.299]}\end{array}$ & $\begin{array}{c}1.242 \\
{[0.070]}\end{array}$ & $\begin{array}{c}0.046 \\
{[0.828]}\end{array}$ & $\begin{array}{l}0.124^{* *} \\
{[2.187]}\end{array}$ & $\begin{array}{c}0.048 \\
{[1.029]}\end{array}$ & $\begin{array}{l}0.155^{\star \star *} \\
{[2.846]}\end{array}$ \\
\hline trend variable (year) & $\begin{array}{c}0.165 \\
{[0.562]}\end{array}$ & $\begin{array}{c}0.348 \\
{[1.181]}\end{array}$ & $\begin{array}{l}-1.165^{*} \\
{[-1.960]}\end{array}$ & $\begin{array}{c}-0.036 \\
{[-0.131]}\end{array}$ & $\begin{array}{c}0.002 \\
{[0.563]}\end{array}$ & $\begin{array}{l}0.011^{* * *} \\
{[3.677]}\end{array}$ & $\begin{array}{l}-0.007^{*} \\
{[-1.826]}\end{array}$ & $\begin{array}{c}0.007^{*} \\
{[1.735]}\end{array}$ \\
\hline constant & $\begin{array}{c}-333.165 \\
{[-0.569]}\end{array}$ & $\begin{array}{c}-698.447 \\
{[-1.187]}\end{array}$ & $\begin{array}{c}2314.894^{*} \\
{[1.954]}\end{array}$ & $\begin{array}{l}64.686 \\
{[0.114]}\end{array}$ & $\begin{array}{c}-3.512 \\
{[-0.501]}\end{array}$ & $\begin{array}{c}-21.620^{\star * \star} \\
{[-3.572]}\end{array}$ & $\begin{array}{l}14.320 * \\
{[1.810]}\end{array}$ & $\begin{array}{l}-13.072 \\
{[-1.735]}\end{array}$ \\
\hline year dummies & $\mathrm{y}$ & $\mathrm{y}$ & $y$ & $\mathrm{y}$ & $y$ & $\mathrm{y}$ & $\mathrm{y}$ & $y$ \\
\hline industry dummies & $\mathrm{y}$ & $y$ & $y$ & $\mathrm{y}$ & $\mathrm{y}$ & $\mathrm{y}$ & $y$ & $\mathrm{y}$ \\
\hline P-Breusch-Pagan & 0 & 0 & 0 & 0 & 0 & 0 & 0 & 0 \\
\hline P-Micro-Small & 0.0343 & & 0.1699 & & 0.0001 & & 0 & \\
\hline P-Small-Medium & 0.0512 & & 0.1198 & & 0 & & 0.0003 & \\
\hline P-Micro-Medium & 0.0175 & & 0.0351 & & 0 & & 0 & \\
\hline observations (N) & 17137 & 17137 & 17137 & 17137 & 17137 & 17137 & 17137 & 17137 \\
\hline clusters (N) & 6166 & 6166 & 6166 & 6166 & 6166 & 6166 & 6166 & 6166 \\
\hline$F$ & 2.903 & 2.79 & 1.331 & 1.505 & 12.523 & 12.233 & 10.03 & 7.902 \\
\hline adjusted r2 & 0.022 & 0.002 & 0.008 & 0.002 & 0.071 & 0.011 & 0.099 & 0.017 \\
\hline prob > F & 0 & 0 & 0.125 & 0.057 & 0 & 0 & 0 & 0 \\
\hline
\end{tabular}

t-values in parenthesis; ${ }^{*} p<0.1,{ }^{* *} p<0.05,{ }^{\star \star *} p<0.01$
P-Breusch-Pagan is the $p$-value in Breusch-Pagan's (1980) test. If the null hypothesis is rejected, the regression disturbances are not normally distributed and heteroskedasticity-consistent estimators of variance are used.

P-Micro-Small is the p-value in a Wald (1940) test that compares the coefficients of the micro and small enterprise dummies. If the null hypothesis is rejected, the coefficients are not equal to each other.

P-Small-Medium and P-Micro-Medium are computed analogously.

The standard errors in all models allow for correlation between mergers by the same acquirer.

The positive and statistically significant coefficients of the size dummies support our previous finding that SMEs which merge during the observed period rely more heavily on external growth than large firms in all three of our measurements. This result is robust, whether we identify micro, small or medium sized firms independently or aggregate them as one category (SME dummy). ${ }^{1}$ When comparing the coefficients of the size dummies (see p-values) we find that they are all statistically different from

1 The large coefficients of the micro firm dummy suggest a robustness check where we exclude all micro firms from the sample and re-estimate the models in Table 8. The results do not change qualitatively. 
each other, with the exception of Model 3, where we normalize deal values with total assets rather than total sales or employee numbers. ${ }^{1}$

Table 9: Cash and Stock as a Means of Payment

\begin{tabular}{|l|ccc|}
\hline Enterprise size & cash $^{*}$ & stock $^{*}$ & other $^{*}$ \\
\hline micro & $18.06 \%$ & $53.05 \%$ & $11.99 \%$ \\
small & $25.97 \%$ & $44.45 \%$ & $13.76 \%$ \\
medium & $31.63 \%$ & $37.61 \%$ & $11.58 \%$ \\
large & $44.22 \%$ & $20.30 \%$ & $7.42 \%$ \\
Total & $41.03 \%$ & $24.59 \%$ & $8.43 \%$ \\
\hline
\end{tabular}

* SME average statistically different from large enterprise average at 0.05 significance level (two-sided ttest)

Figure 1: Average percent of stock in consideration over years and types of enterprises.

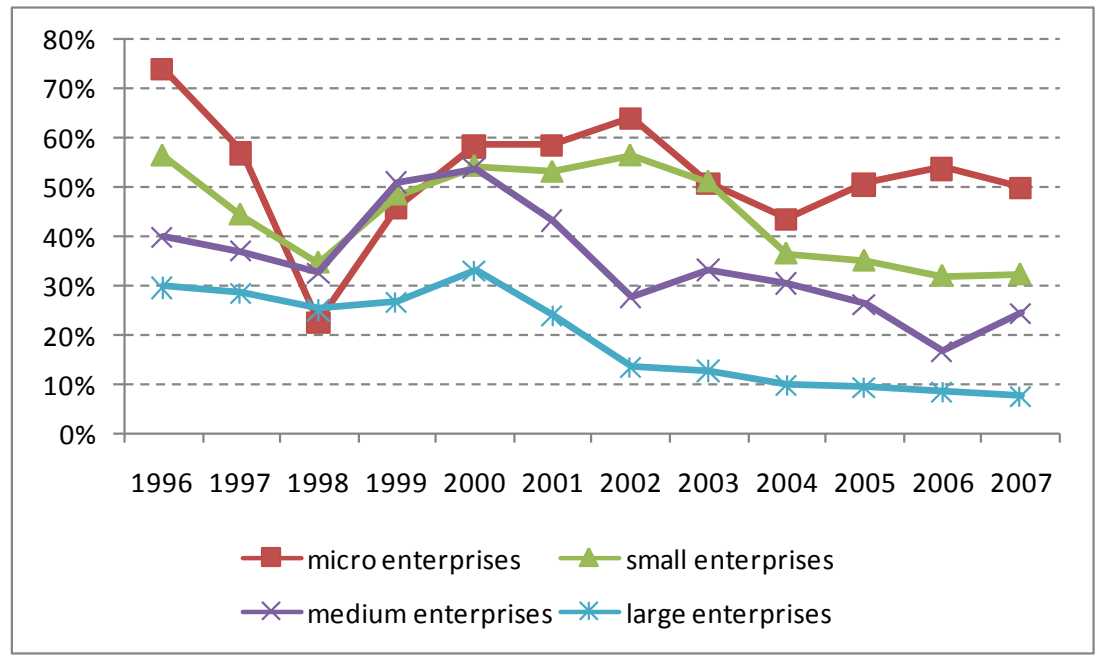

\subsection{Hypothesis Three: On Merger Finance and the Pecking Order}

Finally, and in looking at our third hypothesis, which suggests that SMEs will use more stock and less cash as means of payment than large enterprises, we consider whether SMEs have a higher/lower stock/cash percentage in their consideration than larger companies. Table 9 presents the result of our investigation, again first on a univariate basis.

From this we can clearly see that the probability that a firm pays with stock decreases quite significantly as the size of the firm grows, while the probability that it pays with cash increases, without exception.

\footnotetext{
${ }^{1}$ We control for industries that may point towards less structural differences in external growth strategies of SMEs in more asset-intensive sectors like manufacturing.
} 
Table 10: Cash and Stock as a Means of Payment

\begin{tabular}{|c|c|c|c|c|c|c|}
\hline \multirow{2}{*}{\begin{tabular}{|l|} 
Dependent \\
OLS estimation \\
\end{tabular}} & \multicolumn{2}{|c|}{$\%$ paid in stock } & \multicolumn{2}{|c|}{$\%$ paid in cash } & \multicolumn{2}{|c|}{$\%$ paid in other } \\
\hline & Model 1 & Model 2 & Model 3 & Model 4 & Model 5 & Model 6 \\
\hline micro enterprise & $\begin{array}{c}46.445^{\star \star \star} \\
{[13.668]}\end{array}$ & & $\begin{array}{l}-30.319^{\star \star \star} \\
{[-11.895]}\end{array}$ & & $\begin{array}{c}6.252^{\star \star \star} \\
{[3.242]}\end{array}$ & \\
\hline small enterprise & $\begin{array}{c}34.548^{\star * *} \\
{[19.774]}\end{array}$ & & $\begin{array}{l}-21.432^{\star * *} \\
{[-13.172]}\end{array}$ & & $\begin{array}{c}6.713^{\star * *} \\
{[6.083]}\end{array}$ & \\
\hline medium enterprise & $\begin{array}{c}21.831^{* * *} \\
{[20.380]}\end{array}$ & & $\begin{array}{c}-12.770^{* * *} \\
{[-11.931]}\end{array}$ & & $\begin{array}{c}4.298^{\star * \star} \\
{[7.399]}\end{array}$ & \\
\hline SME & & $\begin{array}{c}25.600^{\star \star *} \\
{[26.180]}\end{array}$ & & $\begin{array}{c}-15.378^{\star * \star} \\
{[-15.525]}\end{array}$ & & $\begin{array}{c}4.873^{\star \star \star} \\
{[9.121]}\end{array}$ \\
\hline acquirer privately owned & $\begin{array}{c}-12.118^{* \star *} \\
{[-3.878]}\end{array}$ & $\begin{array}{c}-11.631^{* * *} \\
{[-3.765]}\end{array}$ & $\begin{array}{c}-12.061^{\star * *} \\
{[-2.787]}\end{array}$ & $\begin{array}{c}-12.390^{* * *} \\
{[-2.894]}\end{array}$ & $\begin{array}{l}-4.721^{* * *} \\
{[-3.025]}\end{array}$ & $\begin{array}{c}-4.620^{* * *} \\
{[-2.947]}\end{array}$ \\
\hline target privately owned & $\begin{array}{l}7.704^{\star * \star} \\
{[11.124]}\end{array}$ & $\begin{array}{l}7.682^{\star \star *} \\
{[11.064]}\end{array}$ & $\begin{array}{c}-7.736^{* \star *} \\
{[-9.580]}\end{array}$ & $\begin{array}{l}-7.720^{* \star *} \\
{[-9.554]}\end{array}$ & $\begin{array}{l}4.293^{* \star *} \\
{[12.440]}\end{array}$ & $\begin{array}{l}4.291^{* \star *} \\
{[12.427]}\end{array}$ \\
\hline target friendly & $\begin{array}{c}0.484 \\
{[0.182]}\end{array}$ & $\begin{array}{c}0.302 \\
{[0.113]}\end{array}$ & $\begin{array}{l}-1.798 \\
{[-0.599]}\end{array}$ & $\begin{array}{l}-1.671 \\
{[-0.554]}\end{array}$ & $\begin{array}{c}1.522 \\
{[1.367]}\end{array}$ & $\begin{array}{c}1.498 \\
{[1.346]}\end{array}$ \\
\hline target size (log deal value) & $\begin{array}{l}4.888^{* \star *} \\
{[24.697]}\end{array}$ & $\begin{array}{l}4.718^{* \star *} \\
{[23.808]}\end{array}$ & $\begin{array}{c}-1.406^{* * *} \\
{[-6.436]}\end{array}$ & $\begin{array}{l}-1.287^{* * *} \\
{[-5.926]}\end{array}$ & $\begin{array}{c}0.775^{\star \star \star} \\
{[8.579]}\end{array}$ & $\begin{array}{c}0.754^{\star \star *} \\
{[8.329]}\end{array}$ \\
\hline acquirer in U.S. & $\begin{array}{c}5.275^{\star \star \star} \\
{[6.741]}\end{array}$ & $\begin{array}{l}5.716^{\star \star \star} \\
{[7.260]}\end{array}$ & $\begin{array}{l}-5.384^{\star \star *} \\
{[-5.136]}\end{array}$ & $\begin{array}{l}-5.698^{\star * *} \\
{[-5.451]}\end{array}$ & $\begin{array}{l}-5.955^{\star \star *} \\
{[-10.443]}\end{array}$ & $\begin{array}{l}-5.923^{\star * \star} \\
{[-10.397]}\end{array}$ \\
\hline trend variable (year) & $\begin{array}{l}-2.083^{* * *} \\
{[-13.271]}\end{array}$ & $\begin{array}{l}-2.015^{* * *} \\
{[-12.788]}\end{array}$ & $\begin{array}{l}1.877^{\star \star \star} \\
{[10.390]}\end{array}$ & $\begin{array}{l}1.830^{* * \star} \\
{[10.100]}\end{array}$ & $\begin{array}{c}-0.107 \\
{[-1.464]}\end{array}$ & $\begin{array}{c}-0.099 \\
{[-1.351]}\end{array}$ \\
\hline constant & $\begin{array}{c}4155.712^{* * *} \\
{[13.220]}\end{array}$ & $\begin{array}{c}4022.857^{* * *} \\
{[12.742]}\end{array}$ & $\begin{array}{c}-3697.257^{* * *} \\
{[-10.229]}\end{array}$ & $\begin{array}{c}-3604.009^{\star * \star} \\
{[-9.941]}\end{array}$ & $\begin{array}{l}219.446 \\
{[1.503]}\end{array}$ & $\begin{array}{r}203.778 \\
{[1.391]}\end{array}$ \\
\hline year dummies & y & y & y & $y$ & y & y \\
\hline industry dummies & $y$ & $y$ & $y$ & $y$ & $y$ & $y$ \\
\hline P-Breusch-Pagan & 0 & 0 & 0 & 0 & 0 & 0 \\
\hline P-Micro-Small & 0.0012 & & 0.0012 & & 0.05 & \\
\hline P-Small-Medium & 0 & & 0 & & 0.425 & \\
\hline P-Micro-Medium & 0 & & 0 & & 0.98 & \\
\hline observations (N) & 17137 & 17137 & 17137 & 17137 & 17137 & 17137 \\
\hline clusters (N) & 6166 & 6166 & 6166 & 6166 & 6166 & 6166 \\
\hline $\mathrm{F}$ & 81.962 & 84.192 & 42.115 & 43.161 & 15.243 & 16.309 \\
\hline adjusted r2 & 0.175 & 0.168 & 0.078 & 0.076 & 0.042 & 0.042 \\
\hline prob > F & 0 & 0 & 0 & 0 & 0 & 0 \\
\hline $\begin{array}{l}\text { t-values in parenthesis; }{ }^{*} p \\
\text { P-Breusch-Pagan is the } p-v \\
\text { disturbances are not norma } \\
\text { P-Micro-Small is the } p \text {-valu } \\
\text { dummies. If the null hypoth } \\
\text { P-Small-Medium and P-Mic } \\
\text { The sic }\end{array}$ & $\begin{array}{l}{ }^{* *} \mathrm{p}<0.05, \\
\text { in Breusc } \\
\text { listributed a } \\
\text { a Wald (19 } \\
\text { is rejected } \\
\text { Medium are }\end{array}$ & $\begin{array}{l}{ }^{* *} p<0.01 \\
\text { Pagan's (1980 } \\
\text { Id heteroskedas } \\
\text { 0) test that com } \\
\text { the coefficients } \\
\text { computed analo }\end{array}$ & $\begin{array}{l}\text { ) test. If the nul } \\
\text { sticity-consister } \\
\text { npares the coef } \\
\text { are not equal t } \\
\text { gously. }\end{array}$ & $\begin{array}{l}\text { I hypothesis } \\
\text { th estimators } \\
\text { ficients of the } \\
0 \text { each other. }\end{array}$ & $\begin{array}{l}\text { cted, the } \\
\text { riance are } \\
0 \text { and sm }\end{array}$ & $\begin{array}{l}\text { ession } \\
\text { d. } \\
\text { nterprise }\end{array}$ \\
\hline
\end{tabular}

Figure 1 shows how this developed over time. From it we can see that stock payments decreased in relative importance during the course of the last merger wave - when the cost of credit was at historical lows - but that the order of preference for stock in SME and large firm M\&As holds constant in almost all years. Micro firms use the most stock in their dealings, small less than that, medium even less, and large firms the least.

To ensure the robustness of this conclusion, and before we accept our hypothesis on the source and nature of SME M\&A financing, we conduct 
OLS regressions using percentage of stock, cash and other means of payment - e.g. acquirer debt directly issued to target shareholders. Table 10 presents the results, and provides clear support for Hypothesis 3.

As suggested by the p-values of the Breusch-Pagan (1980) test, we use heteroskedasticity-consistent estimators of variance in all models. We also test whether the coefficients of the size dummies are equal and reject this null hypothesis in all cases but two (differences to medium sized firms in Model 5). In other words, we do not find a difference between medium sized firms and other SME size categories when we look at payments that are neither cash nor stock. Although interesting as an additional insight, this result does not weaken the support for Hypothesis 3. Firstly, Hypothesis 3 predicts differences between SMEs and large firms, not within SMEs. Secondly, when we focus on the use of stock and cash as preferred methods of payment we find highly significant differences between all size groups: micro, small, medium, and large (Models 1-4).

\section{Conclusions}

In this paper we noted that the existing M\&A literature is dominated by the analysis of larger firms making large deals, and suggested that SMEs may differ from these in their acquisition behaviour. We presented direct and indirect evidence to illustrate this point, and showed that the conduct and financial success of mergers, by entrepreneurial firms, is indeed significantly different to large public firms. To account for this, we considered the applicability of the dominant motivating theories - the theories of efficiency, market power and corporate control, managerial hubris, discretion, and entrenchments, Q-theory, raider theory and empire building - as well as the pecking-order theory of merger finance. We made a number of modifications to the theory of mergers and acquisitions, by adapting and translating the literature on large M\&As to the special situation of SMEs. In the process we came to a number of conclusions:

(1) There are proportionally more SME M\&As in Europe than in the US. Our results show that about $30 \%$ of Western European M\&A were by SMEs. As much of the European merger regulation focuses on large M\&As, our findings indicate a possible need for more differentiated policies with respect to SMEs M\&As.

(2) Smaller firms are more likely to withdraw from $M \& A$ agreement, and seem to be more flexible in walking away from value-destroying mergers. Our results support the conclusion that larger firms perform less well in M\&As, and the suggestion that the large losses made by the 
few may blot out the small successes made the many, when analysed in average terms.

(3) Merger theory needs to be modified for SME M\&As. Our results indicate that agency costs are significantly reduced for SMEs, and that boundedly rational value-destroying actions are less likely to be seen through to their conclusion. Accordingly, we suggest that merger theory needs to be updated for the special case of SME M\&A.

(4) $M \& A$ s are a more popular growth strategy for SMEs. Our results show that M\&As are popular options for SMEs, and even more so than for large firms. This again stresses the importance of more differentiated M\&A policies.

(5) Smaller firms finance $M \& A$ primarily with stock. Our results show that the pecking order hypothesis only partially applies to SMEs, and that this too needs to be updated for the special case of SMEs.

In doing so, this paper provides both direct and indirect evidence, which suggests that small firms behave and perform differently in their mergers and acquisitions. Our paper thus contributes to a better understanding of SME M\&As and why these are so different to the large public acquirers typically studied within the wider literature.

Data limitations loom large in the study of SME M\&As, however and we suggest that much work still needs to be done to better understand these special firms. Clearly subject definitions need to be agreed upon, and an exploration of appropriate performance measures - or proxies - for SME M\&As would make a valuable contribution to the literature.

\section{References}

Agrawal, A., and R.A. Walkling, (1994) Executive careers and compensation surrounding takeover bids. Journal of Finance, 49: 985-1014.

Amihud, Y., and B. Lev, (1981), Risk Reduction as a Managerial Motive for Conglomerate Mergers, Bell Journal of Economics 12, 605-617.

Andrade, G., M. Mitchell, and E. Stafford, (2001) New Evidence and Perspectives on Mergers, Journal of Economic Perspectives 15(2), 103-120.

Atkinson, J., and N. Meagre, (1994) Running to a Stand Still: The Small Business in the Labour Market, in Atkinson, J. and D. Storey (eds), Employment, the Small Firm and the Labour Market, Routledge, London.

Bae, K.H., J.K. Kang and J.M. Kim (2002) Tunneling or value added? Evidence from mergers by Korean business groups, Journal of Finance, 57: 2695-2740 
Banerjee, A., and E.W. Eckard, (1998) Are mega-mergers anticompetitive? Evidence from the first great merger wave. Rand Journal of Economics, 29: 803-827.

Bargeron, L.L., F.P Schlingemann, R.M. Stulz, and C.J. Zutter, (2008) Why do private acquirers pay so little compared to public acquirers?, Journal of Financial Economics 89, 375-390.

Berkovitch, E., M.P. Narayanan, (1993) Motives for Takeovers: An Empirical Investigation, Journal of Financial and Quantitative Analysis 76(1), 347-362.

Berle Jr., A.A., and G.C. Means, (1932) The Modern Corporation and Private Property, MacMillan, New York.

Black, B., (1989), Bidder Overpayment in Takeovers, Stanford Law Review Vol. 41, No. 3, 597-660. Feb., 1989.

Breusch, T., and A. Pagan, (1980) The LM Test and its Applications to Model Specification in Econometrics, Review of Economic Studies 47(1): 239-54.

Bruner, R. F. (1988) The use of excess cash and debt capacity as a motive for merger. Journal of Financial and Quantitative Analysis, 23: 199-217.

Carline, N, S. Linn and P. Yadav, (2002) The Impact of Firm-Specific and DealSpecific Factors on the Real Gains in Corporate Mergers and Acquisitions: An Empirical Analysis. University of Oklahoma Working Paper

Carpenter, R. E., (1995) Finance Constraints or Free Cash Flow? A New Look at the Life Cycle Model of the Firm, Empirica 22: 185-209

Carow, K., R. Heron, and T. Saxton, (2004) Do early birds get the returns? An empirical investigation of early-mover advantages in acquisitions. Strategic Management Journal, 25: 563-585

Cefis, E., S. Rosenkranz, and U. Weitzel, (2008) Effects of coordinated strategies on product and process R\&D, Journal of Economics, DOI 10.1007/s00712008-0041-z

Chang, S., (1998) Takeovers of privately held targets, methods of payment, and bidder returns. Journal of Finance 53: 773-784.

Chatterjee, S., (1986) Types of Synergy and Economic Value: The Impact of Acquisitions on Merging and Rival Firms, Strategic Management Journal 7, 119-139.

Cyert, R.M., and J.G. March (1963) A behavioral theory of the firm. Englewood Cliffs, Prentice-Hall:NJ.

Damanpour, F., (1987) The adoption of technological, administrative, and ancillary innovations: Impact of organizational factors. Journal of Management 13: 675-688.

Deakins, D., and M. Freel, (2006) Entrepreneurship and Small Firms, MacGraw Hill, London

Devos, E., P.R. Kadapakkam, and S. Krishnamurthy, S. (2008) How Do Mergers Create Value? A Comparison of Taxes, Market Power, and Efficiency Improvements as Explanations for Synergies, Review of Financial Studies, doi:10.1093/rfs/hhn019.

Dickerson, A., A.H. Gibson, and E. Tsakalotos, E. (1997) The Impact of Acquisitions on Company Performance: Evidence from a Large Panel of UK Firms, Oxford Economic Papers 49 (3), 344-361. 
Dong, M., D. Hirschleifer, S. Richardson, and S.H. Teoh, (2006) Does Investor Misevaluation Drive the Takeover Market? Journal of Finance 61(2), 725762.

European Commission, (2005) The New SME Definition: User Guide and Model Declaration, DG Enterprise and Industry Publications.

Feinberg, R.M., (1985) Sales at Risk: A Test of the Mutual Forbearance theory of Conglomerate Behaviour, Journal of Business 58, 225-241.

Goergen, M., and L. Renneboog, (2004) Shareholder Wealth Effects of European Domestic and Cross-Border Takeover Bids, European Financial Management 10(1), 9-45.

Gugler, K., D.C. Mueller, B.B. Yurtoglu, and C. Zulehner, (2003) The effects of mergers: an international comparison, International Journal of Industrial Organization 21, 625-653.

Harford, J., (1999) Corporate Cash Reserves and Acquisitions, Journal of Finance 54 (6), 1969-1997.

Hasbrouck, J., (1985) The Characteristics of Takeover Targets: Q and Other Measures, Journal of Banking and Finance 9, 351-362.

Hayward, M. L. A., and D.C. Hambrick, (1997) Explaining the premiums paid for large acquisitions: Evidence of CEO hubris. Administrative Science Quarterly, 42: 103-127.

Hitt, M.A., J.S. Harrison, and R.D. Ireland, (2001) Mergers and Acquisitions: A Guide to Creating Value for Stakeholders, Oxford University Press, Oxford.

Houston, J.F., C.M. James, and M.D. Ryngaert, (2001) Where Do Merger Gains Come From? Bank Mergers from the Perspective of Insiders and Outsiders. Journal of Financial Economics 60: 285-331.

Huang, Y. S., and R. A. Walkling, (1987) Target abnormal returns associated with acquisition announcements-Payment, acquisition form, and managerial resistance. Journal of Financial Economics, 19: 329-349

Jensen, M.C., (1986) Agency Costs of Free Cash Flow, Corporate Finance and Takeovers, American Economic Review, 76, 323-329.

Jensen, M.C., (2005) Agency Costs of Overvalued Equity, Financial Management 34(1).

Johnson, P., (2007) The Economics of Small Firms, Routledge, London.

Jovanovic, B., and P. Rousseau, (2002) The Q-Theory Of Mergers, American Economic Review 92 (2), 198-204.

Kim, E. H., and V. Singal, (1993) Mergers and market power: Evidence from the airline industry. American Economic Review, 83: 549-569.

King, D. R., D.R. Dalton, C.M. Daily, and J.G. Covin, J. G. (2004) Metaanalyses of post-acquisition performance: Indications of unidentified moderators. Strategic Management Journal, 25: 187-200.

Klein, P. G., (2001) Were the acquisitive conglomerates inefficient? Rand Journal of Economics, 32: 745-761

Lang, L., R. Stulz, and R. Walkling, (1991) A Test of the Free Cash Flow Hypothesis: The Case of Bidder Returns, Journal of Financial Economics 29(2), 315-335. 
Lewellen, W., C. Loderer, and A. Rosenfeld, (1985) Decisions and Executive Stock Ownership in Acquiring Firms, Journal of Accounting and Economics 7, 209-231.

Malmendier, U., and G. Tate, (2008) Who makes acquisitions? CEO overconfidence and the market's reaction. Journal of Financial Economics, 89: 20-43.

Malmendier, U., and G. Tate, (2005) CEO Overconfidence and Corporate Investment, Journal of Finance 60(6), 2661-2700.

Manne, H.G., (1965) Mergers and the Market for Corporate Control, Journal of Political Economy 73, 110-120.

Marris, R.L., (1964), The Economic Theory of Managerial Capitalism, MacMillan, London

Marris, R.L. (1963) A Model of 'Managerial' Enterprise, Quarterly Journal of Economics 77(2), 185-209

Martynova, M., and L. Renneboog, (2008) A Century of Corporate Takeovers: What Have We Learned and Where Do We Stand? Journal of Banking and Finance 32(10), 2148-2177.

Moeller, S.B., F.P. Schlingemann, and R.M. Stulz, (2004) Firm size and the gains from acquisitions, Journal of Financial Economics 73, 201-228.

Moeller, S.B., F.P. Schlingemann, and R.M. Stulz, (2005) Wealth Destruction on a Massive Scale? A Study of Acquiring-Firm Returns in the Recent Merger Wave, Journal of Finance 60(2), 757-782.

Moses, D.O., (1992) Organizational slack and risk-taking behavior: Tests of product pricing strategy. Journal of Organizational Change Management 5: 38-54.

Motta, M., (2004) Competition Policy Theory and Practice, Cambridge University Press, Cambridge.

Mueller, D.C., (1969) A Theory of Conglomerate Mergers, Quarterly Journal of Economics 83, 643-659.

Mukherjee, T.K., H. Kiymaz and H.K. Baker (2004) Merger Motives and Target Valuation: A Survey of Evidence from CFO's. Journal of Applied Finance 14: 7-24.

Myers, S., and N. Majluf, (1984) Corporate Financing and Investment Decisions When Firms Have Information That Investors Do Not Have. Journal of Financial Economics 13: 187-221.

Nohria, N., and R. Gulanti, (1996) Is slack good or bad for innovation? Academy of Management Journal 39: 1245-1264

Officer, M.S., (2007) The Price of Corporate Liquidity: Acquisition Discounts for Unlisted Targets. Journal of Financial Economics 83: 571-598.

Palepu, K.G., (1986) Predicting Takeover Targets: A Methodological and Empirical Analysis, Journal of Accounting and Economics 8, 3-35.

Prager, R. A., (1992) The effects of horizontal mergers on competition: The case of the Northern Securities Company. Rand Journal of Economics, 23: 123133.

Puranam, P., and H. Singh, (1999) "Rethinking M\&A for the high technology sector", Wharton School Working Paper, Presented at AOM 2000 meetings. 
Rau, P.R., and T. Vermaelen, (1998) Glamour, Value and the Post-Acquisition Performance of Acquiring Firms, Journal of Financial Economics 49, 101116.

Ravenscraft, D.J., and F.M. Scherer, (1987) Mergers, Sell-offs and Economic Efficiency. The Brookings Institution: Washington,DC.

Rhoades, S.A., (1983) Power, Empire Building and Mergers, D.C Heath \& Co, Lexington MA.

Roll, R., (1986) The Hubris Hypothesis of Corporate Takeovers, Journal of Business 59, 197-216.

Sapienza, P., (2002) The Effects of Banking Mergers on Loan Contracts. The Journal of Finance LVII: 329-367.

Scharfstein, D., (1988) The Disciplinary Role of Takeovers, Review of Economic Studies 55(2), 185-199.

Schlingemann, F., (2004) Financing Decisions and Bidder Gains. Journal of Corporate Finance 10: 683-701.

Schwert, G., (1996) Markup pricing in mergers and acquisitions. Journal of Financial Economics 41, 153-192.

Shleifer, A., and R.W. Vishny, (1989) Management Entrenchment: The Case of Manager-specific Investments, Journal of Financial Economics 25(1), 123139.

Shleifer, A., and R.W. Vishny, (1991) Takeovers in the '60s and the '80s: Evidence and Implications, Strategic Management Journal 12, 51-59.

Singh, J.V., (1986) Performance, slack and risk-taking in organizational decision making. Academy of Management Journal 29: 562-585

Storey, D., (1994) Understanding the Small Firm Sector, Routledge, London.

Wald, A., (1940). The Fitting of Straight Lines if Both Variables Are Subject to Error. Annals of Mathematical Statistics 11(3): 284-300.

Wan, W.P., and D.W. Yin, (2009) From crisis to opportunity: environmental jolt, corporate acquisitions, and firm performance. Strategic Management Journal DOI:10.1002/smj.744:

Weitzel, U., and S. Berns, (2006) Cross-border takeovers, corruption, and related aspects of governance, Journal of International Business Studies 37, 786-806.

Weston, F.J., M.L. Mitchell and H.J. Mulherin, (2004) Takeovers, Restructuring and Corporate Governance, Pearson Prentice Hall, Upple Saddle River, New Jersey.

Williamson, O.E., (1964) The Economics of Discretionary Behavior, PrenticeHall, Englewood Cliffs NJ.

WilmerHale (2007), 2006 Merger Report, Wilmer Cutler Pickering Hale and Door LLP, available at http://www.wilmerhale.com 